\title{
Zatížení tekoucích vod organickým znečištěním v závislosti na ekonomickém vývoji v České republice
}

\section{TOMÁŠ ZAPLETAL}

Klíčová slova: environmentální Kuznetsova křivka - ekonomický rozvoj - kvalita vod - matematický model - BSK 5 - CHSK Cr $_{5}$

\section{SOUHRN}

Vztah mezi ekonomickým rozvojem a kvalitou tekoucích vod byl hypoteticky testován použitím modelu Environmentální Kuznetsovy křivky (EKC) - období let 1979-2019. Dva hlavní indikátory organického znečištění, BSK ${ }_{5}$ and CHSK $_{\mathrm{Cr}^{\prime}}$ vyjadřovaly vývoj kvality vody. Konsolidovaná řada dat HDP byla využita pro model EKC za posledních zhruba 10 let socialistické ekonomiky a následné změny v ekonomiku tržní. Bylo zjištěno, že vývoj obou indikátorů je plynule sestupný s výjimkou posledních pěti let. Následný výzkum EKC pro jiné znečištuující látky a země, jakož i aplikace dalších metodických prístupů, by mohly přispět k lepšímu pochopení modelu EKC, včetně ekonomických a sociálních předpokladů jeho platnosti, a jeho teoretického kontextu.

\section{ÚVOD}

Znečištování vodního prostředí polutanty přináší negativní ekologické dopady, které $v$ praxi znamenají omezení nebo znemožnění obecného nakládání s vodami. Dochází tak k celkovému znehodnocení vodního systému nejenom pro vodní organismy, ale také např́klad pro úpravu vody pro průmysl, nebo vodárenské využití. Vznikají tak vedlejší náklady, které př́mo nejsou promítnuty do ceny výrobků - negativní externality [1]. Tyto negativní externality druhotně přinášejí ztrátu jiným subjektům [2]. Formou restriktivních nástrojů jsou tvůrci negativních externalit nuceni investovat část nákladů do snižování emisí polutantů. Postupně tak dochází ke zlepšení stavu a poklesu křivky [3].

Jedním z modelů vyjádření mezi časovým vývojem, indikátory znehodnocování životního prostředí per capita a výší hrubého národního produktu na osobu je Environmentální Kuznetsova křivka (EKC) [4]. Vztah má v ideálním případě tvar obráceně postaveného písmene "U“ [5]. S industriálním rozvojem společnosti dochází ke stále většímu zatížení životního prostředí, avšak za jistých okolností tento jev Ize považovat za akceptovatelný vedlejší efekt ekonomického růstu [6]. Vzestupný trend v časové ose není trvalý. Při naplnění environmentální kapacity začíná docházet k negativnímu dopadu znečištění na život společnosti. Společnost je nucena nadměrné znečištění kvůli jeho negativním důsledkům pro společnost a prírodu řešit. Cílem environmentální politiky je v koncovém procesu zajistit nové environmentálně šetrnějši technologie [7]. Prosazování těchto technologických změn je uskutečněno pưsobením trhů i regulací ze strany státu.
Organické znečištění povrchových vod indikují v dlouhodobých časových řadách nejlépe dva ukazatele - BSK $_{5}$ - biochemická spotřeba kyslíku a CHSK Cr $_{-}$ chemická spotřeba kyslíku. Problém dostupnosti dat spočivá ve skutečnosti, že ukazatele v podmínkách ČR začaly být dlouhodobě systematicky monitorovány až v sedmdesátých letech minulého století, zatímco největší nárůst zatížení vod těmito polutanty spadá do období industrializace společnosti v letech padesátých a šedesátých. Z tohoto důvodu v modelu EKC postrádáme větší část transcendentní části křivek.

Cílem výzkumu bylo ověřit, jak ve vodním hospodářství ČR probíhá vztah mezi ekonomickým růstem a organickým znečištěním tekoucích vod od 70. let minulého století. Výsledky výzkumu tak mohou překlenout mezeru v poznání ekologicko-ekonomických scénárư a porovnat je s rámcem podobných modelů provedených v jiných zemích.

\section{METODIKA}

Modelování EKC bylo provedeno konsolidovanými daty o úrovni ekonomické výkonnosti národního hospodářství České republiky. Hrubý domácí produkt na osobu (HDP/P), spočtený výrobní metodou (ceny 2019), byl převzat z databáze národních účtů vedené Českým statistickým úřadem [8]. Míra znečištování vod za období let 1979-2019 byla určena z ročních emisních bilancí stacionárních zdrojů znečištování vod - ukazatele BSK $_{5}$ a $\mathrm{CHSK}_{\mathrm{c}}$.

$\mathrm{BSK}_{5}$ - biochemická spotřeba kyslíku indikuje míru organického biologicky odbouratelného znečištění za pět dní při konstantní teplotě $20^{\circ} \mathrm{C}$. $\mathrm{CHSK}_{\mathrm{cr}}$ - chemická spotřeba kyslíku indikuje oxidaci, které některé organické látky podlehnou vlivem oxidačních činidel. V tomto případě je oxidačním činidlem dichroman draselný. Těmito daty disponujeme $v$ ČR v poměrně dlouhé časové řadě a dostatečně indikují míru organického znečištění vod.

Výsledky byly interpretovány formou Giniho indexu [9] podle vzorce (1):

$$
G=2 \cdot \int[p-L(p)] d p
$$

kde $p-L(p)$ je funkce tzv. skóringového modelu.

Projekce dat do modelu EKC, představující oddělení křivky zátěže životního prostředí a křivky ekonomického výkonu byla provedena $v$ software $\mathrm{R}$ core 3.6.2. [10]. 
Odhad standardního regresního modelu EKC pro oba emisní ukazatele byl proveden modifikovanou rovnicí [11] (2):

$$
\ln (E / P)=\beta 1 * \ln (G D P / P)+\beta 2 *(\ln (G D P / P)) 2+\varepsilon
$$

kde $E$ je objem emisí,

$P$ početnost populace,

GDP hrubý domácí produkt,

In prirozený logaritmus.

\section{VÝSLEDKY A DISKUSE}

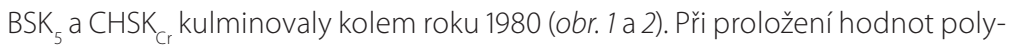
nomickým trendem je zřejmé, že po sestupu v období let 1981-2014 dochází v posledním pětiletém období k jejich ustálení. Určit bod zlomu je vzhledem k částečné absenci vzestupného trendu obtižné, nicméně z výsledků je patrné, že by se měl nacházet v oblasti HDP/P - 46500 Kč.

Posouzení odhadu obou EKC pomocí Sternovy rovnice a z ní odvozeného matematického modelu přinesly velmi signifikantní průkaznost výše popsaného vývoje. Při standardní chybě výběrového průměru 0,18, resp. 0,22, a t hodnotě 9,7, resp. 9,8, nám v obou prípadech vychází $P<0,05^{*}$ - průkazná diference a zároveň $P<0,01^{* *}$ vysoce průkazná diference.

Výzkum EKC se od počátku odehrával v rovině teoretické a empirické, které byly vzájemně propojeny. V teoretické rovině se jednalo o syntézu dosavadních poznatků a vklínění vlastních výsledků do tohoto rámce. $V$ empirické rovině bylo cílem zkoumat EKC v úrovni platnosti pro jednotlivé ukazatele organického znečištění tekoucích vod a jejich vazbě na HDP.

Teoretický výzkum ekonomických dopadů na vodní prostředí započal Frisch [12]. Model EKC ještě nebyl $v$ této době znám a tak se jednalo o vyjádření míry znečištění pomocí číselných indexů. Následující teoretické modely byly založeny na agregovaných produkčních funkcích a vysvětlované veličiny jako kvantita a kvalita byly konfrontovány s rozvojem kapitálu a technologií [13]. Po formulování EKC prošel tento model dlouhodobým vývojem a kritikou, že projekt je chybný. Mnoho autorů se následně věnovalo odlišným výzkumům, např́klad Lopez [14] se zabýval zkoumáním liberalizace obchodu na EKC, zatímco koncept ekonomického prístupu podle Matkowského a Prochanika [15] byl sestaven ze dvou hledisek, nárůstu HDP/P a ekonomického růstu napříc regiony a tendencí zátěžového parametru v ekonomickém cyklu.

Model EKC $v$ současném kontextu je zaznamenán $v$ celosvětovém měřítku [16], převážně však v Asii [17, 18]. V postkomunistických zemích je situace nejlépe zmapována na Ukrajině [19]. Vzhledem k opožděnému trendu oproti zemím západní Evropy se kolektivu těchto autorů podařilo namodelovat z dostupných dat celou EKC $v$ jednovrcholové dynamice.

Empirická analýza byla provedena na ověření platnosti EKC pro vývoj úrovní degradace životního prostředí. Provedení takového modelu přináší také sekundární prínos, kterým je vytvoření jednoho z podkladů pro výpočet marketingového bodu zvratu pro konkrétní polutanty a úrovní důchodů a spotřeby na hlavu [20].

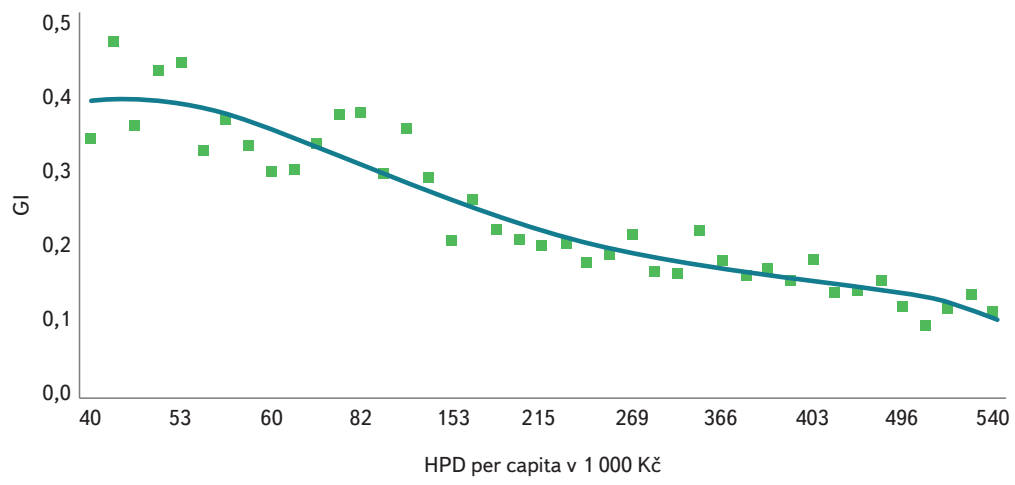

Obr. 1. Model EKC pro BSK - ČR 1979-2019, GI - Giniho index

Fig. 1. EKC model for BOD in the Czech Republic between 1979 and 2019, GI - Gini index

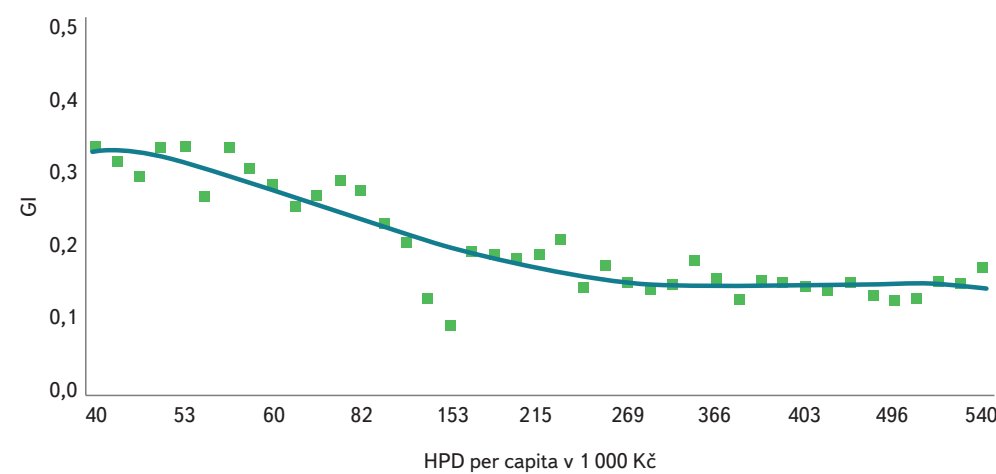

Obr. 2. Model EKC pro CHSK cr $_{-}$ČR 1979-2019, Gl - Giniho index

Fig. 2. EKC model for COD in the Czech Republic between 1979 and 2019, GI - Gini index

Vlastní výsledky a jejich přesná interpretace jsou závislé zejména na správném výběru datových sad a jejich statistickém vyhodnocení [21]. Sestavení datasetu $\vee$ našem prípadě bylo omezeno dostupností dat o úrovni environmentálního znečištění v časové ose. Z výsledkové řady uvedené výše vyplývá průkazné snížení emisí polutantů v závislosti na růstu HDP/P, ale výklad nemusí být vždy jednoznačný. Např́klad Katz [22] zjistil, že pouze podíl průmyslu na národní produkci sleduje trajektorii typu Kuznets, neplatí to však pro ostatní determinanty, jakými jsou např́klad služby nebo zemědělská produkce.

Předložené výsledky naznačují, že navrhovaný koncept modeluje pozitivní vývoj postupného snižování znečištění životního prostředí v závislosti na postupném bohatnutí společnosti. Taková situace však může platit jen pro vyspělé industriální ekonomiky. V globálním měřítku lze předpokládat další nárůst degradace životního prostředí. Přispívá k tomu prèlidnění planety, příjmová nerovnost $v$ jednotlivých třídách společnosti, neschopnost vlád jednotlivých zemí spolu účinně spolupracovat. Ke zlepšení může vést koordinace národních politik rozvoje životního prostředí v konsekvenci udržitelného rozvoje.

Souhrnně Ize uvést, že projekt EKC byl přes smíšená hodnocení pozitivně přijat [23]. K interpretaci výsledků je však zapotřebí přistupovat kriticky, protože

Tabulka 1. Vývoj počtu čistíren odpadních vod v ČR a jejich celkové kapacity

Table 1. Development and total capacity of wastewater treatment plants in the Czech Republic

\begin{tabular}{lcccccc} 
Ukazatel & $\mathbf{2 0 0 0}$ & $\mathbf{2 0 0 5}$ & $\mathbf{2 0 1 0}$ & $\mathbf{2 0 1 5}$ & $\mathbf{2 0 1 6}$ & $\mathbf{2 0 1 7}$ \\
\hline Počet ČOV & 1055 & 1994 & 2188 & 2495 & 2554 & 2612 \\
\hline Celk. kapacita ČOV (tis. $\mathrm{m}^{3} /$ den) & 3927 & 3736 & 3798 & 3916 & 3930 & 3914 \\
\hline
\end{tabular}


jsou podmíněny mnoha faktory. Kterými jsou napríklad druh znečištující látky a její disperze ve vodním prostředí, typ a metodika měření polutantů ve vodách, počet zkoumaných proměnných, státní zřizení, institucionální a vládní politika a použité ekonomické modely [24].

Počet čistíren odpadních vod se od počátku století prudce navyšuje (tabulka 1). S tím je spojena vzrůstající celková kapacita ČOV. Vyjádřit jednoznačně jejich účinnost není jednoduché [25]. Záleží na druhu použité technologie a také dodržení technologické kázně obsluhy zařízení. Pokles emisí do vodního prostředí je také způsoben rozvojem nových technologií čištění odpadních vod. Ekonomika se tak může rozvíjet bez dalšího negativního vlivu na životní prostředí. Je to také důležité z důvodu probíhající klimatické změny a z ní vyplývajícího dlouhodobého období sucha. Při snížení průtoků dochází ke „zkoncentrování” zbytkového znečištění.

$\checkmark$ posledních dvaceti letech došlo k poklesu produkce znečištěných odpadních vod o 21 \% [26]. Tato skutečnost je způsobena nejenom systémem recirkulací a šetření vodou, ale také uplatňováním „čistší" produkce a technologií [27].

\section{ZÁVĚR}

Environmentální Kuznetsova křivka byla ověřena pro prípad organického znečištování vod v České republice v časovém horizontu 1979-2019. Výsledky přináší možnou interpretovatelnost a zevšeobecnitelnost testovaného modelu. Bylo zjištěno, že v podmínkách rozvinuté ekonomiky postkomunistické země přináší nárůst HDP vhodné prostředí k omezení takových negativních externalit, jakými jsou emise polutantů organického znečištění vod. Největší slabinou modelu je nedostupnost dat v období pred rokem 1979 - v modelu tudíz absentuje vzestupná část EKC. I přes tento nedostatek je s modelem možné pracovat a využít jej pro další makroekonomické analýzy.

\section{Poděkování}

Výsledky šetření byly provedeny v rámci Projektu č. F/2/15/2019 - Ekonomie a politika pstruhového rybolovu Fakulty mezinárodních vztahů VŠE v Praze. Touto cestou děkujeme za finanční podporu.

\section{Literatura}

[1] SOUKUP, J. Mikroekonomická analýza. Melandrium Praha, 2003, 256 s.

[2] MORRIS, J. Sound Resources Management. Oregon Department of Environmental Quality, 2013, s. 19. [3] GROSSMANN, G.M. and KRUEGER, A.B. Environmental Impact of a North America Free Trade Agreement. Working Papers 3914. National Bureau of Economic research, Cambridge, MA. 1991.

[4] KUZNETZ, S. Economic Growth and Income Inequality. American Economic Review, 1955, Vol. 45, p. 1-28.

[5] DINDA, S. Environmental Kuznets Curve Hypothesis: A Survey. Ecological Economics, 2004, Vol. 49, No. 4, p. $831-455$

[6] ARROW, K., BOLIN, B., CONSTANZA, R., DASOUPTA, P., FOLKE, C., HOLLING, C.S., JANSSON, B.O. LEVIN, S., MELLER, K.G., PERRINGS, C., and PIMENTEL, D. Economic Growth, Carrying Capacity, and the Environment. Science, 1995, Vol. 268, p. 520-521.

[7] KREUZ, J., LISA, A. a ŠAUER, P. Environmentální Kuznetsova křivka v podmínkách České republiky v období let 1975-2012. Politická ekonomie, 2017, roč. 65, č. 1, s. 119-130

[8] Český statistický úrad. HDP, národní účty 2019. Dostupné z: https://www.czso.cz/csu/czso/ hdp_narodni_ucty

[9] DUARTE, R., PINILLA, V., and SERRANO. A. Is there an environmental Kuznets curve for water use? A panel smooth transition regression approach. Economic modelling, 2013, Vol. 31, p. 518-527.

[10] CRAWLEY, M.J. The RBook. John Wiley \& Sons, Ltd, 2007, p. 942.

[11] STERN D.I. The Rise and Fall of the Environmental Kuznets Curve. World Development, 2004, Vol. 32 No. 8, p. 1419-1439.

[12] FRISCH, R. The Problem of Index Numbers. Econometrica, 1936, Vol. 4, No. 1, p. 1-38.
[13] BARRO R.J and SALA-I-MARTIN X Convergence across states and regions. Brookings Papers on Economic Activity, 1991, p. 107-182.

[14] LOPEZ, R. The Environment as a Factor of Production: The Effects of Economic Growth and Trade Liberalization. Journal of Environmental Economics and Management, 1994, Vol. 27, No. 2, p. 163-284

[15] MATKOWSKI, Z. and PROCHANIK, M. Real economic convergence in the EU accession countries. International Journal of Applied Econometrics and Quantitative Studies, 2004, Vol. 1, p. 5-38.

[16] FARRIS, F.A. The Gini Index and Measures of Inequality. The American Mathematical Monthly, 2010, p. 851-864.

[17] MA, B., TIAN, G. and KONG, L. Spatial-temporal characteristics of China's industrial wastewater discharge at different scales Environmental Science and Polution Research, 2020, Vol. 27, No. 8 p. 8103-8118

[18] WANG, Y. Urban land and sustainable resource use: Unpacking the countervailing effects of urbanization on water use in China, 1990-2014. Land Use Policy, 2020, Vol. 90, p. 1-9.

[19] MELNYK, L.G., KUBATKO, O.V., and KUBATKO, O.V. Were Ukrainian regions too different to star interregional confrontation: economic, social and ecological convergence aspects? Economic Research-Ekonomska Istraživanja, 2016, Vol. 29, No. 1, p. 573-582

[20] BARBIER, E.B. Introduction to the Environmental Kuznets Curve Special Issue. Environment and Development Economics, 1997, Vol. 2, No. 4, p. 369-381.

[21] HETTIGE, H. MANI, M., and WHEELER, D. Industrial pollution in economic development: the Environmental Kuznets Curve Revisited. Journal of Development Economic, 2000, Vol. 62, No. 2. p. $445-476$

[22] KATZ, D. Water use and economic growth: reconsidering the Environmental Kuznets Curve relationship. Journal of Cleaner production, 2015, Vol. 88, No. 1, p. 205-213.

[23] DASGUPTA, S., LAPLANTE, B., WANG, H., and WHEELER, D. Confronting the Environmental Kuznets Curve. The Journal of Economic Perspectives, 2002, Vol. 16, No. 1, p. 146-168.

[24] STERN, D.I., COMMON, M.S., and BARBIER, E.B. Economic Growth and Environmental Degradation: the Environmental Kuznets Curve and Sustainable Development. World Development 1996, Vol. 24, No. 7, p. 1151-1160

[25] NOVÁK, L. a BENEŠ, O. Limity biologické čistitelnosti odpadnich vod 2017. Dostupné z: http:// vodnihospodarstvi.cz/limity-biologicke-cistitelnosti-odpadnich-vod

[26] Český statistický úr̆ad. Vodovody a kanalizace v ČR 2018. Dostupné z: https://www.czso.cz/csu/ czso/ceska-republika-od-roku-1989-v-cislech-2018\#02

[27] FRESNER, J. Cleaner production as a means for effective environmental management. Journal o Cleaner Production, 1998 , Vol. 6, p. 171-179.

\section{Autor}

Ing. Tomáš Zapletal, Ph.D. et Ph.D.

凶zapt00@vse.cz

ORCID: 0000-0002-8045-5018

Katedra politologie, Fakulta mezinárodních vztahů, Vysoká škola ekonomická v Praze

Príspěvek prošel lektorským řízením.

DOI: 10.46555/VTEI.2020.04.001 


\section{ORGANIC POLLUTION OF \\ STREAMS DEPENDS ON ECONOMIC DEVELOPMENT IN CZECH REPUBLIC}

\section{ZAPLETAL, T.}

Department of Political Science, Faculty of International Relations, University of Economics in Prague

Keywords: Environmental Kuznets Curve - economic development water quality - mathematical model - BOD - COD

The relationship between economic development and stream water quality in the Czech Republic between 1975 and 2019 was assessed based on an Environmental Kuznets Curve (EKC) model using two main organic pollution indicators: Biochemical Oxygen Demand (BOD) and Chemical Oxygen Demand (COD). By including a consolidated time series of Gross Domestic Product (GDP), it was possible to apply the EKC over a ca. 15-year period covering both the socialist economy and the period following its transition to a market economy. The results show that, aside from the last five years, development of both $B O D$ and COD quantity decreased consistently. Future research using EKC models and other methodological approaches on different pollutants and in other countries will contribute to both a better understanding of the EKC model itself, including the economic and social preconditions for its validity, and its theoretical context. 